\title{
ASSESSMENT OF PRESIDENTE GETÚLIO WATERFALLS BATHING CONDITIONS - SANTA CATARINA STATE, BRAZIL
}

\author{
BAGATTOLI, F. ${ }^{1 ;}$ SERBENT, M.P. ${ }^{2 *}$; CENSI, G. ${ }^{3}$; BACHMANN. S.A.L. ${ }^{4}$ \\ 1. City Hall of Presidente Getúlio \\ 2. Santa Catarina State University (UDESC) \\ 3. Federal University of Rio Grande do Sul (UFRGS) \\ 4. Rio Grande do Sul Federal Institute of Education, Science and Technology (IFRS) \\ *Corresponding author: mariapilar.serbent@udesc.br
}

\begin{abstract}
Bagattoli, F. ${ }^{1}$, Serbent, M.P. ${ }^{2}$, Censi, G. ${ }^{3}$ \& Bachmann. S.A.L ${ }^{4}$ (2018). Assessment of Presidente Getúlio waterfalls bathing conditions - Santa Catarina State, Brazil. Braz. J. Aquat. Sci. Technol. 22(1). elSSN 1983-9057. DOI: 11139/ bjast.v22n1. Human actions without proper planning can result in degradation of water bodies by compromising their varied uses, and among them, their recreational use. The district of Presidente Getúlio, in the Alto Vale do Itajaí region, Santa Catarina State, Brazil, has several waterfalls that serve as recreation environments. However, there is a lack of studies to assess the environmental quality of these areas. The objective of this study was to evaluate the bathing conditions of four waterfalls in Presidente Getúlio according to the bathing criteria established by Brazilian law. The indicative parameters of water quality evaluated were Escherichia coli, $\mathrm{pH}$, dissolved oxygen, temperature, turbidity and biochemical oxygen demand. The results indicate that the waterfalls have improper conditions of primary contact recreation due to pollution from various sources (fecal matter from livestock activities) and other sources (untreated domestic sewage). Fecal pollution of these recreational water bodies can lead to health problems due to the presence of infectious microorganisms.
\end{abstract}

Key Words: Waterfall, water quality, monitoring.

\section{INTRODUCTION}

The use of water resources for recreation is very common in Brazil and seems to be increasing, apparently driven by the demand for activities in contact with the natural environment as an 'antidote' to modern urban life (Lopes et al., 2014; Lopes et al., 2016). Waterfalls, rivers and reservoirs stand out among the freshwater environments with more utilization for primary contact recreation (Lopes et al., 2014). However, despite the prevalence of water-based recreation, there have been few studies and monitoring programs in Brazil to assess conditions for bathing, especially in freshwaters which are frequently contaminated by farmland runoff, domestic and industrial wastewater and stormwater (Lopes et al., 2014; Lopes et al., 2015). Regular monitoring of water resources is therefore important for proper management strategies. Waterfalls, most of which are formed from stream or river which cascade from a high elevation over a cliff or rock, had very little attention from researchers from all over the world (Offem \& Ikpi, 2011).

The Brazilian framework for surface water quality is an important water management tool and establishes a water quality classification based on water uses and environmental standards for freshwater, saltwater and brackish water ecosystems (Brazil, 2005). The setting up of an adequate legislation for the protection of the water quality is a crucial point for the environmental development of all countries (Schmidt et al., 2008).

According to the World Health Organization (WHO, 2003), the two principal components required for assessing fecal contamination of recreational water areas are: assessment of evidence for the degree of influence of fecal material (i.e. derivation of a sanitary inspection category), and counts of suitable fecal index bacteria (a microbial water quality assessment). These would be done for classification purposes only where recreational water is used for whole-body contact recreation. In Brazil, water conditions for bathing are defined by means of CONAMA Resolution No. 274/2000 that establishes standards to classify water bodies as proper or improper for bathing use (Brazil, 2000).

For quantifying microbial contaminants that are dangerous to public health, fecal indicator bacteria (FIB) is used worldwide as indicator of the potential presence of dangerous pathogens that can be found in water used for bathing, drinking and harvesting of seafood. The "indicator" system relies on the assumption that FIB are present concomitant to the presence of human bacterial, viral and parasitic pathogens of concern (Mesquita \& Noble, 2013). In addition, the current methodology established by CONAMA Resolution No. $274 / 2000$ is restricted to limited indicators (Lopes et al., 2015).

The district of Presidente Getúlio, Santa Catarina State, Brazil, has several waterfalls, which are 
quite frequented by bathers in search of recreation in the summer season. However, there is a lack of studies to assess the environmental quality of these water bodies. In this sense, the objective of this study was to evaluate the bathing conditions of four waterfalls located at the district of Presidente Getúlio, according to the bathing criteria established by Brazilian law.

\section{MATERIAL AND METHODS}

\section{Study area}

The present study was conducted on four waterfalls, in the district of Presidente Getúlio (27\%03'02"S and $49^{\circ} 37^{\prime} 22$ "W), Alto Vale do Itajaí, Santa Catarina (SC), Brazil (Figure 1).

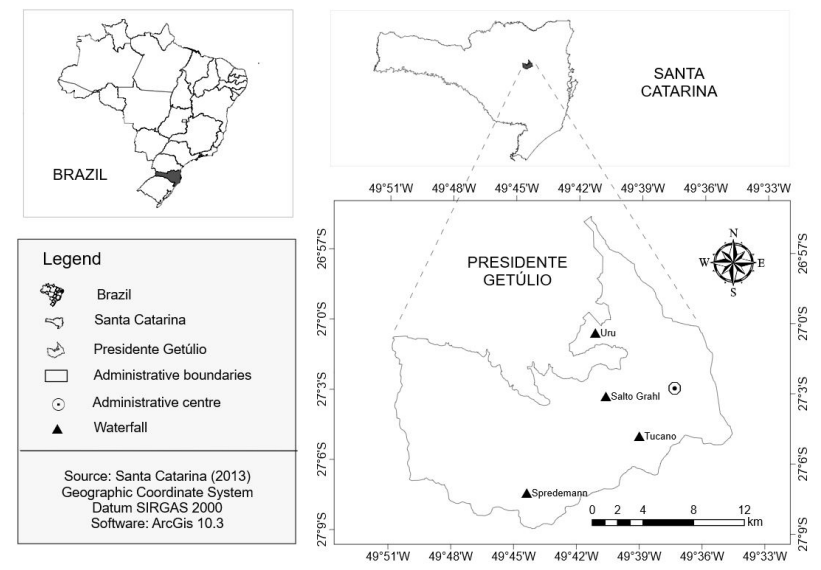

Figure 1 - Localization of the study area.

Presidente Getúlio has a land area of about $294.26 \mathrm{~km}^{2}$. The urban area is restricted to the surroundings of the Administrative Centre, occupying only $8.69 \mathrm{~km}^{2}$ of the total area (2.95\%) (Presidente Getúlio, 2008).

According to the latest census by the Brazilian Institute of Geography and Statistics (Brazil, 2010), the population of Presidente Getúlio is 14,887 , of which 10,535 (about $71 \%$ ) live in urban area and 4,352 (29\%) live in rural area.

The climate is classified as humid mesotherm, without dry season and with hot summers. The average relative humidity is $83 \%$ and the annual precipitation is from 1.3 to 1.5 thousand millimeters. The wettest months are January and February, with an average precipitation of $170 \mathrm{~mm}$. The driest months are April, May, June and July, with an average precipitation of $90 \mathrm{~mm}$. The average annual temperature is $18^{\circ} \mathrm{C}$. January and February are the hottest months (average of about $25^{\circ} \mathrm{C}$ ). June and July are the coldest months (average of about $15^{\circ} \mathrm{C}$ ) (Pandolfo et al., 2002).

The natural vegetation is the Mixed Ombrophilous Forest type (Araucarias Forest) (Brazil, 2004).

For the reference year of 2015, the service and industry sectors are the ones that contribute most to the Gross Domestic Product (GDP) of the district of Presidente Getúlio. Roughly, the service sector accounts for $\mathrm{R} \$ 178$ million per year $(41 \%)$, while the industrial sector contributes $\mathrm{R} \$ 174$ million (40\%) and the agricultural sector $\mathrm{R} \$ 41$ million $(9 \%)$. In taxes the municipality collects about $\mathrm{R} \$ 41$ million (9\%) (Brazil, 2015).

Service and industry activities are present in the urban area of the district, while agricultural activities occur more commonly in the rural area.Considering the last Census of Agriculture (Brazil, 2006), the main products grown in the district of Presidente Getúlio are corn, tobacco, manioc and beans. The production of orange and mandarin is also outstanding. The herd consists mainly of chickens, pigs and cattle. The economic activities of industry and agriculture are related to the land use and, consequently, can interfere in the environmental quality of the water bodies, such as waterfalls. For identification and selection of waterfalls with greater recreational potential in the municipality of Presidente Getúlio, consultations were carried out at tourist information centers, municipalities, and various sources of dissemination of tourist routes, making it possible to identify the main waterfalls used for primary contact recreation. The four waterfalls selected for the study are named: Salto Grahl, Spredemann, Tucano and Uru.

Throughout the human occupation of the land, crops and pastures for animal husbandry replaced the native forest. This also occurred in regions near the waterfalls of the district.

The Salto Grahl and Tucano waterfalls are located within the urban area, approximately $6 \mathrm{~km}$ and 5 $\mathrm{km}$ away from the Administrative Centre, respectively. The Uru and Spredemann waterfalls are located in the rural area, approximately $8 \mathrm{~km}$ and $15 \mathrm{~km}$ away from the Administrative Centre, respectively.

The regions around the Salto Grahl, Tucano and Uru waterfalls are greatly altered by human action. In the immediate vicinity of these waterfalls there is still native forest remaining but residences, roads, crops and pastures mainly occupy the areas.

The Spredemann waterfall still has its natural characteristics preserved, as it is further away from the population core of the district. On the other hand, near the waterfall, agricultural and livestock activities are developed.

\section{Sampling campaigns and limnological variables}

In order to assess the bathing conditions, five surface water samples were weekly collected in the four waterfalls. The sampling procedure was based on the Brazilian Normatives NBR 9897/87 (ABNT, 1987a) and NBR 9898/87 (ABNT, 1987b), and CONAMA 
Resolution No. 274/2000 (Brazil, 2000).

The sampling campaigns took place in October and November of 2015, in the following dates: first collection was in $10 / 06 / 2015$; second collection was on $10 / 13 / 2015$; third collection was on $10 / 20 / 2015$; fourth collection was on 10/27/2015; and fifth collection was on $11 / 03 / 2015$. Therefore, the samples were collected before the recreational season (from December to February).

Table 1 presents the limnological variables and the analysis methods.

Table 1 - Limnological variables and analysis methods

\begin{tabular}{|c|c|c|c|}
\hline Parameter & Measurement & Preservation & Analysis Method \\
\hline DO & in-situ & - & \multirow{3}{*}{$\begin{array}{l}\text { Multi-parameter measuring } \\
\text { device AKSO, model AK88 }\end{array}$} \\
\hline Temperature & in-situ & - & \\
\hline $\mathrm{pH}$ & In-situ & - & \\
\hline Turbidity & Ex-situ & $\begin{array}{l}\text { Glass bottles, } \\
\text { refrigerated at } \\
4^{\circ} \mathrm{C}\end{array}$ & $\begin{array}{c}\text { Portable turbidimeter MS } \\
\text { Tecnopon }\end{array}$ \\
\hline BOD & Ex-situ & $\begin{array}{l}\text { Glass bottles } \\
\text { (sterilized), } \\
\text { refrigerated at } \\
4^{\circ} \mathrm{C} \\
\end{array}$ & $\begin{array}{l}\text { BOD-meter Aqualytic, } \\
\text { model OxiDirect. }\end{array}$ \\
\hline E. coli & Ex-situ & $\begin{array}{l}\text { Glass bottles } \\
\text { (sterilized), } \\
\text { refrigerated at } \\
4^{\circ} \mathrm{C}\end{array}$ & $\begin{array}{l}\text { Colilert and Quanti-Tray } \\
\text { Method }\end{array}$ \\
\hline \multicolumn{4}{|c|}{$\begin{array}{l}\text { DO - Dissolved Oxygen } \\
\text { pH - potential of Hydrogen } \\
\text { BOD - Biochemical Oxygen Demand } \\
\text { E. coli - Escherichia coli }\end{array}$} \\
\hline
\end{tabular}

All the ex-situ analytical procedures were performed according to the Standard Methods for Examination of Water and Wastewater (APHA, 1998) in the Water's Quality and Sanitary Microbiology Laboratories at Santa Catarina State University - Udesc, Ibirama campus. In order to investigate the presence of pathogenic microorganisms, bacteriological analyzes were performed using Escherichia coli (E. coli) ( $T$. Escherich, 1885) as indicator of fecal contamination.

The method of chromogenic substrate (APHA Method 9923 B), was used for bacteriological determinations. This method allows determining both total coliforms and $E$. coli in the samples, either the qualitative and quantitative manners.

For investigation of potential sources of pollution (natural or anthropogenic), dissolved oxygen (DO) and Biochemical Oxygen Demand (BOD) (Standard Method 5210 B) were evaluated as well (Di Bernardo \& Sabogal Paz, 2008; Esteves, 2011; Von Sperling, 2014).

The parameters potential of Hydrogen $(\mathrm{pH})$, $\mathrm{DO}$ and temperature were measured with a Portable Multiparameter Meter (AK88).

For turbidity analysis, water was collected in 200 $\mathrm{ml}$ glass vials at each site. Then, the samples were transported refrigerated (in a thermal box containing ice) for quantification using a turbidimeter (MS Te- cnopon), calibrated every week on the day of sample collection.

For BOD and E. coli, characterization analyses of the samples were listed based on Lopes et al. (2014) and the definition of the parameters was performed taking into account CONAMA Resolution No. 274/2000. The inclusion of other parameters aimed to evaluate impacts on the safety and comfort of bathers, in this case, $\mathrm{pH}$, temperature and turbidity (Australia, 2008; Martins, 2012; Lopes et al. 2014).

\section{RESULTS}

After the five-week sampling campaign and considering the results of physicochemical and microbiological determinations (Table 2), a classification of the bathing conditions was performed for the four waterfalls.

Table 2 - Measured values of the parameters of the four waterfalls

\begin{tabular}{|c|c|c|c|c|c|c|c|}
\hline \multirow[b]{2}{*}{ Week } & \multirow[b]{2}{*}{ Waterfall } & \multicolumn{6}{|c|}{ Parameters } \\
\hline & & $\begin{array}{l}\text { E. coli } \\
\text { (NMP.100 } \\
\text { mL-1) }\end{array}$ & $\begin{array}{c}\mathrm{BOD}_{5,20} \\
\left(\mathrm{mgO}_{2} \mathrm{~L}^{-1}\right)\end{array}$ & $\mathrm{pH}$ & $\begin{array}{c}\mathrm{DO} \\
\left(\mathrm{mg} \cdot \mathrm{L}^{-1}\right)\end{array}$ & $\begin{array}{c}\text { Temperature } \\
\left({ }^{\circ} \mathrm{C}\right)\end{array}$ & $\begin{array}{l}\text { Turbidity } \\
\text { (NTU) }\end{array}$ \\
\hline \multirow{4}{*}{1} & Spredemann & 184.9 & BLQ & 7.71 & 6.9 & 15.7 & 7.71 \\
\hline & Salto Grahl & 1076.6 & BLQ & 7.51 & 6.9 & 17.6 & 30.77 \\
\hline & Tucano & $>2419.6$ & BLQ & 7.63 & 5.2 & 16.3 & 17.01 \\
\hline & Uru & $>2419.6$ & 3 & 7.70 & 5.1 & 17.3 & 21.41 \\
\hline \multirow{4}{*}{2} & Spredemann & 795.4 & BLQ & 7.51 & 6.2 & 19.3 & 23.46 \\
\hline & Salto Grahl & 1444.1 & BLQ & 7.21 & 5.8 & 20.1 & 58.00 \\
\hline & Tucano & 1817.4 & BLQ & 7.66 & 6.6 & 19.8 & 42.91 \\
\hline & Uru & 779.2 & BLQ & 7.41 & 5.7 & 19.5 & 32.37 \\
\hline \multirow{4}{*}{3} & Spredemann & 473.9 & BLQ & 7.33 & 9.1 & 19.9 & 20.00 \\
\hline & Salto Grahl & $>2419.6$ & BLQ & 7.18 & 5.0 & 20.7 & 54.00 \\
\hline & Tucano & $>2419.6$ & BLQ & 7.72 & 10.8 & 21.5 & 42.00 \\
\hline & Uru & 1054.7 & ALQ & 7.43 & 4.9 & 21.9 & 76.00 \\
\hline \multirow{4}{*}{4} & Spredemann & 643.7 & ALQ & 7.49 & 6.3 & 20.6 & 15.50 \\
\hline & Salto Grahl & $>2419.6$ & BLQ & 7.33 & 8.5 & 21.0 & 57.00 \\
\hline & Tucano & 1203.3 & BLQ & 7.56 & 4.9 & 20.8 & 45.00 \\
\hline & Uru & 1384.2 & BLQ & 7.66 & 8.9 & 20.8 & 41.00 \\
\hline \multirow{4}{*}{5} & Spredemann & 1795.4 & BLQ & 7.52 & 5.9 & 20.2 & 18.20 \\
\hline & Salto Grahl & $>2419.6$ & BLQ & 7.46 & 6.8 & 21.6 & 94.00 \\
\hline & Tucano & $>2419.6$ & BLQ & 7.66 & 7.4 & 21.0 & 39.00 \\
\hline & Uru & 2130.7 & 0 & 7.48 & 7.5 & 21.2 & 29.00 \\
\hline \multicolumn{3}{|c|}{$\begin{array}{l}\text { E. coli - Escherichia coli } \\
\text { BOD - Biochemical Oxygen Demand } \\
\mathrm{pH} \text { - potential of Hydrogen }\end{array}$} & \multicolumn{5}{|c|}{$\begin{array}{l}\text { BLQ - Below the Limit of Quantification }\left(<0 \mathrm{mg} \mathrm{O}_{2} \mathrm{~L}^{-1}\right) \\
\text { ALQ - Above the Limit of Quantification }\left(>200 \mathrm{mg} \mathrm{O}_{2} \mathrm{~L}^{-1}\right)\end{array}$} \\
\hline
\end{tabular}

For categorization of the waterfalls, CONAMA Resolution No. 274/2000 standards were followed, for which only the parameters $E$. coli and $\mathrm{pH}$ are required. Also, for the values of DO and BOD, CONAMA Resolution No. 357/2005 for water bodies class two $\left(\mathrm{BOD} \leq 5 \mathrm{mgO}_{2} \cdot \mathrm{L}^{-1}\right.$ and $\mathrm{OD} \geq 5 \mathrm{mg} \cdot \mathrm{L}^{-1}$ ) were established as evaluation criteria, since the waterfalls evaluated belong to this classification. The values of turbidity and temperature are compared to the values stipulated by the international legislation on the topic of bathing.

\section{Microbiological analysis of fecal contaminations}

Based on the obtained results, Grahl, Tucano and Uru waterfalls had E. coli values greater than the limit established by Brazilian legislation (800NMP. $100 \mathrm{~mL}^{-1}$ ) for $80 \%$ or more of the analyzed samples. Therefore, this water bodies were classified 
as unsuitable for primary contact recreation to this parameter. The Spredemann waterfall, in turn, presented satisfactory results only between the second and fourth week.

\section{Dissolved Oxygen}

Throughout the monitoring period, the results for dissolved oxygen for all waterfalls were in accordance with CONAMA Resolution No. 357/2005 for water bodies class 2 . All the values were higher than the minimum limit established by legislation $\left(5 \mathrm{mg} \cdot \mathrm{L}^{-1}\right)$.

\section{Biochemical Oxygen Demand}

During the sampling period, the BOD results for Salto Grahl and Tucano waterfalls were below the detection limit of the equipment, and thus, in accordance with the CONAMA Resolution No. 357/2005 $\left(<5 \mathrm{mgO}_{2} \cdot \mathrm{L}^{-1}\right)$ (Table 2$)$. In the case of Spredemann waterfall, it is noted that at the fourth week of sampling campaign the resulting value was above the limit of quantification of the equipment $\left(>200 \mathrm{mgO}_{2} \cdot \mathrm{L}^{-1}\right)$, i.e. non-conforming with the limits stipulated by CONAMA Resolution No. 357/2005. The same situation was verified for Uru waterfall at the third week.

\section{Temperature}

Despite the absence of a Brazilian normative for temperature, the registered values during the monitoring period for all sampling sites were in accordance with international recommendations to safely recreational activities $\left(15 \leq^{\circ} \mathrm{C} \leq 35\right)$ (Australia, 2008).

\section{Turbidity}

For turbidity determination, at the five-week sampling campaign the values for Spredemann and Salto Grahl waterfalls were in accordance to Brazilian law, CONAMA Resolution No. 357/2005 for primary contact recreation (turbidity values $\leq 100 N T U$ - Nephelometric Turbidity Unit). In the particular case of Salto Grahl waterfall, only at the first week of water samples collecting, a lower value (30.77NTU) than the reference value stipulated by the law was observed. For Uru waterfall, turbidity values were within the limits recommend, except at the third week of monitoring, where a sharp increase in the turbidity value was observed (76.00NTU). It is important to highlight that CONAMA Resolution No. 274/2000 does not establish limits for turbidity. Therefore, according to CONAMA resolution No. 357/2005, freshwater bodies can be considered as belonging to 1 and 2 Classes if their turbidity values are lower than 40 and $100 N T U$, respectively. According to CONAMA Resolution No. 357/2005, if the quality of the water body is unknown, it must be classified as Class 2, and thus the turbidity limit for the purpose of this study was set at $100 \mathrm{NTU}$.
$\mathrm{pH}$

According to CONAMA Resolution No. 274/2000, the $\mathrm{pH}$ of a water body under analysis must be in a range between 6.0 and 9.0 to be considered suitable for bathing. For all waterfalls, the $\mathrm{pH}$ values were in conformity with parameters established by the mentioned resolution.

\section{DISCUSSION}

In this paper, we have presented the results of five weeks water monitoring previously to summer season for the four most utilized waterfalls in Presidente Getúlio location, Santa Catarina State, Brazil.

Throughout the development of this study, it is possible to conclude that the four evaluated waterfalls showed unsuitable conditions for recreational primary contact, according to the standards set by CONAMA Resolution No. 274/2000 for the assessment of conditions for bathing in freshwater in Brazil. According to the $\mathrm{pH}$ and $E$. coli determinations, the water presented potential health risks for the population that uses the waterfalls for leisure.

The $\mathrm{pH}$ value is important because it has a strong relationship with bacterial growth. Most bacteria grow best around neutrality $(\mathrm{pH} \mathrm{7.0)}$, with the range being from about pH 6.5 to 7.5 (Doetsch \& Cook, 2012). In the case of $E$. coli, it can multiply at $\mathrm{pH}$ between 5.0 and 9.0 (Gonzales et al., 2013). Also, pH is a parameter that determines the dissolution, precipitation, oxidation and reduction of various substances (Bourg et al., 1995), so it is determinant for the self-depuration capacity of aquatic environments.

Likewise, temperature influences biological processes and chemical and biochemical reactions. In the case of $E$. coli, the optimal temperature for its development is $37^{\circ} \mathrm{C}$ (Gadgil et al., 2005), but the microorganism is also capable of surviving in an environment which temperature is between $8^{\circ} \mathrm{C}$ and $45^{\circ} \mathrm{C}$ (Bastos, 2009).

The high concentrations of $E$. coli evidenced that sanitary conditions in the waterfalls were seriously degraded by fecal pollution. According to the latest census by the Brazilian Institute of Geography and Statistics (Brazil, 2010), the district of Presidente Getúlio presents $86.5 \%$ of households with adequate domestic sewage collection and treatment. However, it is worth mentioning that the city's rainwater collection system works as a unitary system, since rainwater, domestic and industrial sewage are disposed of in this single collector.

In addition, there is no collective sewage treatment system in the city. The main solution used to treat domestic sewage is the septic tank, installed in each household. On the other hand, this type of 
treatment system often does not receive adequate maintenance, which compromises the efficiency of the sewage treatment. When the untreated domestic sewage reaches the water body, organic matter and pathogens contaminate the water. This could explain the values of $B O D$ and $E$. coli parameters.

The observed values for the BOD and E. coli parameters can also be explained by the presence of livestock pastures near waterfalls. Bacteria and other microorganisms can reach the water body through the drainage of rainwater that get in touch with animal faeces raised freely in areas near waterfalls. In the same way, organic matter present in the crops can be carried to the water bodies by the rainwater flow.

In this perspective, waterfalls can be polluted by point sources, such as by the discharge of untreated sewage, or by diffuse sources, such as by the drainage of contaminated rainwater.

The results indicate fecal contamination and may be associated with the fact that this study was developed during heavy rain times in the study area. According to information from the civil defense of Presidente Getúlio District, during the period in which the sampling campaigns were conducted (OctoberNovember, 2015) it rained about 317 millimeters. Thus, the influence of surface runoff has possibly led to quality of the baths investigated.

Lopes and Magalhães Jr. (2010) carried out the monitoring of nine bathhouses in the Alto Rio das VeIhas basin (Minas Gerais, Brazil) during rainy and dry seasons. They proved that during the period with high rainfall of sites classified as unfit for primary contact recreation were higher than those of dry season (five improper at rainy season, one improper at dry season). The authors concluded that the surface runoff (during the rainy season) is the factor that contributes most to the change in the microbiological quality of water.

Water quality evaluation can be used as an indicator of human activity in a watershed (Haddad \& Magalhães, 2010). Turbidity is one of the main water quality parameters able to demonstrate the interference of land use and occupation of a basin in the river dynamics (Silva et al., 2003). The importance of turbidity monitoring is related to vectors of waterborne diseases. As turbidity increases, the risk of pathogenic microorganisms increases (WHO, 2011).

Excessive suspended sediment concentration (SSC) can degrade water quality. The sunlight and heat interception in the water due to high SSC reduces photosynthesis, which is essential to the health of water bodies, and modifies the aquatic ecosystem. Furthermore, sediment deposits can decrease water depth, hampering navigation and causing local floods more frequently (Kobiyama et al., 2011).

In rainfall events, turbidity in water bodies increases due to solids drags and suspension, in general, accompanied by an increase in the number of fecal coliforms. This characterizes a situation of a higher susceptibility to water pollution occurrence at rainy season, with trends worsening the water quality (Haddad \& Magalhães, 2010). In this sense, accelerated erosion can reveal the loss of the natural balance in a watershed, leading to changes in the fluvial depositional environments (Raposo et al., 2010). The physicochemical characterization methods of particles (shape, size, surface properties) were recently considered in particular because of the sensitivity of turbidity to these parameters. A very good correlation between turbidity and $E$. coli $\left(R^{2}=0.93\right)$ has been demonstrated for colloidal particles $(0.9 \leq \mu \mathrm{m} \leq 1.5)$ (Jung et al., 2014).

Thus, the waterfalls need attention from the local (environmental department) and state (FATMA - environmental foundation) authorities. According to CONAMA (Brazil, 2000), the identification and signaling of unsuitable recreational areas in Brazil is a responsibility of the competent environmental authority (municipal, state or federal). Moreover, considering that the tourism potential of Presidente Getúlio is closely correlated to its natural attractions, especially waterfalls, the installation of sewage treatment plants or another type of wastewater treatment technology are crucial, so that the water quality can meet the requirements of the current regulations.

However, it should be noted that this study included only five weeks of sampling campaign, according to recommendations of CONAMA (Brazil, 2000). To reach a consistent evaluation of the waterfalls quality, a continuous monitoring of all recreational waterfalls in the municipality it is recommended. Long-term monitoring is essential in order to give a fair indication of 'typical' conditions and avoid undue influence of relatively brief episodes of fecal pollution, for example (Lopes et al., 2016).

Despite of current Brazilian legislation provides a suitable framework for environmental pollution control (Schmidt et al., 2008), the normative that deals with the bathing conditions (CONAMA Resolution No. $274 / 2000$ ) should be updated to include standards for turbidity and cyanobacteria, considering that these variables can compromise the recreational use of water for primary contact purposes. However, algal and cyanobacterial blooms are a concern in terms of health, due to the release of cyanotoxins. In addition, the presence of these organisms can make water bodies aesthetically repulsive for recreational use by the accumulation of organic matter and the possibility of unpleasant odors. Therefore, it is important to consider algal and cyanobacterial parameters for classification and evaluation of freshwater bathing conditions (Lopes et al., 2014). Furthermore, the number of coliforms or $E$. 
coli, used as indicators of biological contamination, is not suitable to indicate the presence of enteric viruses and protozoans (Lopes et al., 2015).

Due to the lack of monitoring and information for users, they may get in contact with contaminated water and thus they are being expose to a high risk of contracting a great number of diseases, especially for the elderly, people with weakened immune systems and children (Lopes et al., 2013). In this context, studies in Brazil have reported the need of other quality parameters of water in addition to $\mathrm{pH}$ and $E$. coli to improve the freshwater bathing evaluation in Brazil (Lopes et al., 2015).

It is crucial to enhance the evaluation methodology of bathing conditions through the introduction of new variables and their respective limiting values to improve the evaluation, and thus ensure better bathing conditions. Through the development of this work, precariousness in monitoring programs that assess the conditions of bathing recreational inland waters in Brazil was perceived. However, the setting up of the legislation must be accompanied by funding availability, strengthening of environmental institutions, commitment from private (industries) and public (water and sanitation companies) and police incentives for improvements in effluent and river water quality (Schmidt et al., 2008). In this context, the need to implement management strategies for bathing areas by the private sector and the municipal authorities is emphasized for other states in Brazil, where leisure activities in waterfalls are important for local economies (Lopes et al., 2011).

The monitoring of water for recreational use program should be planned and effectuated considering the provision of information about bathing conditions to users at certain times, and allow the construction of a representative data series to support the management process of recreational waters (Lopes et al., 2014).

Presidente Getúlio has been exploring its tourism potential with the effort of the municipal administration to develop local and regional tourism in an organized way, seeking new attractions and itineraries (Agente Comunica, 2016; SANTUR, 2017). Tourism is growing and increasingly contributing to the economy of the district, especially in the service sector. However, potential explotation of tourism may be threatened by environmental degradation, especially water body degradation.

Presidente Getúlio is known as the "Valley of the Waterfalls" (SANTUR, 2017). Among other natural refuges, waterfalls are the main attraction of the city. Water quality in these natural areas can be a limiting factor for tourism, and thus have significant economic impacts (Silva et al., 2014; Lopes et al., 2016).

As suggestion for future studies, it is advisable to develop a broader research project involving more recreational areas, not just in Presidente Getúlio, but throughout the Alto Vale de Itajaí region, where cities like Rio do Sul, Ibirama, José Boiteux, Vitor Meireles, among others, have places that are frequently visited by people seeking leisure resorts.

\section{CONCLUSION}

The Salto Grahl, Spredemann, Tucano and Uru waterfalls have improper conditions of primary contact recreation due to pollution caused by diffuse sources and point sources. The pollution of these recreational water bodies can lead to health problems and can adversely affect the tourism activities in the district of Presidente Getúlio.

The long-term assessments in areas used for bathing could contribute to the preparation of action plans by the environmental agencies, from the possibility of identifying the actual water quality for bathing and their main pressure sources due to interference in environmental factors. However, long-term evaluations aim to support the management process of water for recreational use and supply the demand for information on the diagnosis of water bodies in order to guide the public goer.

It is also recommended to extend the monitoring period that comprises at least one year of research, including dry and rainy seasons, and thus be able to compare the results obtained in both periods. Furthermore, it is suggested an analysis of the use and occupation of the land surrounding the evaluated sites to identify and characterize the main water pollution sources.

\section{ACKNOWLEDGEMENTS}

The authors would like to thank FAPESC for the financial support.

\section{REFERENCES}

ABNT. Associação Brasileira de Normas Técnicas. 1987a. NBR 9897: Planejamento de amostragem de efluentes líquidos e corpos receptores Procedimento. Rio de Janeiro: ABNT, 14p.

ABNT. Associação Brasileira de Normas Técnicas. 1987b. NBR 9898: Preservação e técnicas de amostragem de efluentes líquidos e corpos receptores - Procedimento. Rio de Janeiro: ABNT, $22 p$.

Agente Comunica. 2016. Presidente Getúlio. Website of the Caminhos do Alto Vale Project, which seeks to promote the tourist potential of the Alto Vale do Itajaí region. Rio do Sul: Agente 
Comunica. http://www.caminhosdoaltovale.com. $\mathrm{br} /$ site/paginas/?pg=presidente-getulio

APHA. American Public Health Association. Standard Methods for Examination of Water and Wastewater. 1998. American Water Works Association, Water Environmental Federation, 20 ed. Washington: APHA.

Australia. NHMRC. National Health and Medical Research Council. 2008. Guidelines for Managing Risks in Recreational Water. Camberra: NHMRC, $215 p$.

Bastos, P.A.M.B. 2009. Sobrevivência de Escherichia coli O157:H7 em logurtes. Doctoral thesis. Bom Jesus do Itabapoana: Universidade Federal Fluminense (UFF).

Brazil. CONAMA. Conselho Nacional de Meio Ambiente. 2000. Directive 274/2000. Brazilian National Environmental Council. Criteria for bathing in Brazilian waters. Brasilia: CONAMA.

Brazil. IBGE. Instituto Brasileiro de Geografia e Estatística. 2004. Mapa de Vegetação do Brasil. Brazilian Institute of Geography and Statistics. Vegetation Map of Brazil. Rio de Janeiro: IBGE.

Brazil. CONAMA. Conselho Nacional de Meio Ambiente. 2005. Directive 357/2005. Brazilian National Environmental Council. Criteria for bathing in Brazilian waters, Classification of water bodies; environmental guidelines for the classification; establishment of conditions and standards for effluent discharge. Brasilia: CONAMA.

Brazil. IBGE. Instituto Brasileiro de Geografia e Estatística. 2006. Censo Agropecuário 2006. Brazilian Institute of Geography and Statistics. Census of Agriculture. Rio de Janeiro: IBGE.

Brazil. IBGE. Instituto Brasileiro de Geografia e Estatística. 2010. Censo 2010. Brazilian Institute of Geography and Statistics. Demographic Census. Rio de Janeiro: IBGE.

Brazil. IBGE. Instituto Brasileiro de Geografia e Estatística. 2015. Produto Interno Bruto dos Municípios 2002-2015. IBGE, em parceria com os Órgãos Estaduais de Estatística, Secretarias Estaduais de Governo e Superintendência da Zona Franca de Manaus - SUFRAMA. Brazilian Institute of Geography and Statistics. Gross Domestic Product of Brazilian Municipalities. Rio de Janeiro: IBGE.

Bourg, A.C.M.; Loch, J.P.G. 1995. Mobilization of heavy metals as affected by $\mathrm{pH}$ and redox conditions. In: SALOMONS, W.; STIGLIANI, W. M. (Org.). Biogeodynamics of pollutants in soils and sediments: risk assessment of delayed and nonlinear responses Germany. Springer, p. 87-102.
Di Bernardo, L. \& Sabogal Paz, L.P. 2008. Seleção de Tecnologias de Tratamento de Água. v. 1. 1 ed. São Carlos: LDiBe, p.817-1016.

Doetsch, R.N.; Cook, T. M. 2012. Introduction to Bacteria and Their Ecobiology. Verlag: Springer, Netherlands, $371 \mathrm{p}$.

Esteves, F.A. 2011. Fundamentos de Limnologia. 3 ed. Rio de Janeiro: Interciência, 826 p.

Gadgil, M.; Kapur, V. \& Hu, W.S. 2005. Transcriptional response of Escherichia coli to temperature shift. Biotechnol Prog, v. 21, n. 3, p. 689-99.

Gonzales, L., Ali, Z.B, Nygren, E., Wang, Z., Karlsson, S., Zhu, B., et al. 2013. Alkaline pH Is a Signal for Optimal Production and Secretion of the Heat Labile Toxin, LT in Enterotoxigenic Escherichia Coli (ETEC). PLoS ONE 8(9): e74069. 12p.

Haddad, E.A. \& Magalhães JR., A.P. 2010. Influência Antrópica na qualidade da água da bacia hidrográfica do rio São Miguel, Carste do Alto São Francisco, Minas Gerais. Revista Geosul, v. 25, n. 49, p. 79-102.

Jung, A.-V., Le Cann, P., Roig, B., Thomas, O., Baurès, E., \& Thomas, M.-F. 2014. Microbial Contamination Detection in Water Resources: Interest of Current Optical Methods, Trends and Needs in the Context of Climate Change. International Journal of Environmental Research and Public Health, v.11, n. 4, p. 4292-4310.

Kobiyama, M.; Mota, A.A.; Grison, F. \& Giglio, J.N. 2011. Landslide influence on turbidity and total solids in Cubatão do Norte River, Santa Catarina, Brazil. Natural Hazards, v. 59, n. 2, p.1077-1086.

Lopes, F.W.A.; Carvalho, A. \& Magalhães JR., A.P. 2011. Levantamento e avaliação de impactos ambientais em áreas de uso recreacional das águas na bacia do Alto Rio das Velhas. Caderno Virtual de Turismo (UFRJ), v. 11, n. 2, p. 177-190.

Lopes, F.W.A.; Magalhães JR., A.P. \& Von Sperling, E. 2013. Balneabilidade em Águas Doces no Brasil: Riscos a Saúde, Limitações Metodológicas e Operacionais. Revista Brasileira de Geografia Médica e de Saúde, v. 9, n. 16, p. 28-47.

Lopes, F.W.A.; Magalhães JR., A.P. \& Von Sperling, E. 2014. Metodologia para avaliação de condições de balneabilidade em águas doces no Brasil. Revista Brasileira de Recursos Hídricos, v. 19, n. 4, p. 124-136.

Lopes, F.W.A.; Von Sperling, E. \& Magalhães JR., A.P. 2015. Indicadores para balneabilidade em águas doces no Brasil. Geografias (UFMG), v. 2, n. 1, p. 6-22.

Lopes, F.W.A.; Davies-Colley, R.J.; Von Sperling, E. \& Magalhães Jr., A.P. 2016. A water quality index for recreation in Brazilian freshwaters. Journal of Water and Health, v. 14, n. 2, p. 243-254. 
Martins, L.K.L.A. 2012. Contribuições para Monitoramento de Balneabilidade de Águas Doces no Brasil. Master thesis. Belo Horizonte: Universidade Federal de Minas Gerais (UFMG).

Mesquita, S. \& Noble, R.T. 2013. Recent Developments in Monitoring of Microbiological Indicators of Water Quality Across a Range of Water Types, Chapter 2. In: Water Resources Planning, Development and Management, Ralph Wurbs (Ed.), London: InTech, p. 29-51.

Offem, B.O. \& Ikpi, G.U. 2011. Water Quality and Environmental Impact Assessment of a Tropical Waterfall System. Environment and Natural Resources Research, v. 1, n. 1, p. 63-74.

Pandolfo, C.; Braga, H.J.; Silva Júnior, V.P.; Massignan, A.M.; Pereira, E.S.; Thomé, V.M.R \& Valci, F.V. 2002. Atlas climatológico do Estado de Santa Catarina. Florianópolis: Empresa de Pesquisa Agropecuária e Extensão Rural de Santa Catarina (Epagri).

Presidente Getúlio. 2008. Lei Complementar n ${ }^{\circ}$ 2292/2008. Guidelines for the territorial planning of the district of Presidente Getúlio. Presidente Getúlio, 75p.

Raposo, A.A.; Barros, L.F.P. \& Magalhães JR., A.P. 2010. O uso de taxas de turbidez da Bacia do Alto Rio das Velhas Quadrilátero Ferrífero/MG como indicador de pressões humanas e erosão acelerada. Revista de Geografia (Recife), v. especial VIII SINAGEO, n. 3, p.34-50.

Schmidt, M.; Glasson, J.; Emmelin, L. \& Helbron, H. (Eds.). 2008. Standards and Thresholds for Impact Assessment. Series: Environmental Protection in the European Union, v. 3. Berlin, Heidelberg: Springer Berlin Heidelberg.

SANTUR. Santa Catarina Turismo S/A. 2017. Presidente Getúlio. Website that publicizes information about tourism in the Santa Catarina State. Florianópolis: SANTUR. http://turismo. sc.gov.br/cidade/presidente-getulio/

Santa Catarina. SEPLAN. Secretaria de Estado do Planejamento. 2013. Limites Municipais. Santa Catarina Government. Florianópolis: SEPLAN. http://sigsc.sds.sc.gov.br/download/

Silva, A.M.; Schulz, H.E. \& Camargo, P.B. 2003. Erosão e hidrossedimentologia em bacias hidrográficas. São Carlos: RiMa, 114 p.

Silva, P.V. da; Piroli, E.L. \& Hernandez, J.E.G. 2014. Qualidade da Água e Turismo em Bacias Hidrográficas: O Caso da Microbacia do Rio Sucuri, Bonito - MS, Brasil. Ciência Geográfica, v. XVIII, n. 1, p.89-101.

Von Sperling, M. 2014. Introdução à Qualidade das Águas e ao Tratamento de Esgotos. 4 ed. Belo
Horizonte: Universidade Federal de Minas Gerais (UFMG), $470 \mathrm{p}$.

WHO. World Health Organization. 2003. Guidelines for safe recreational water environments. v. 1, Coastal and fresh waters. Geneva: WHO, 253 p.

WHO. World Health Organization. 2011. Guidelines for Drinking Water Quality. 4th ed. Geneva: WHO, $564 p$.

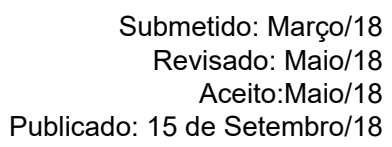

ubmetido: Março/18 Aceito:Maio/18

Publicado: 15 de Setembro/18 